\title{
Trainees' day, North West Region, 22 May 1989
}

\author{
LiseTtA M. LOVETT, Lecturer, University of Liverpool; and MICHAEL BROWNLEe, Senior \\ Registrar, North Manchester General Hospital (CTC representatives)
}

This year's North West CTC Trainees' Day took place at the Prestwich Conference Centre on 22 May. The morning session was chaired by Professor John Copeland of Liverpool University and its theme was politics and psychiatry. The afternoon session consisted of two simultaneously run workshops on 'How to do Research', chaired by Dr Abou-Saleh, Senior Lecturer, Liverpool University and 'The New MRCPsych Exam' chaired by Dr S. Benjamin, Senior Lecturer, Manchester Royal Infirmary.

Dr Dafydd Huws, our first speaker, is a consultant psychiatrist at Whitchurch Hospital, Cardiff and National Chairman of Plaid Cymru. His talk, entitled 'Politics, Culture and Psychiatry' began by stressing the danger in psychiatry of allowing ideology to supplant the inquisitive, scientific mind. Inquisitive evaluation, he told us, was inversely proportional to ideological conviction. He went on to expound his own views on how culture impinges on psychiatry. This included reference to the effect on psychiatric morbidity of increasing urbanisation, suburbanisation and geographical mobility as well as declining religious conviction. He widened his talk to include an analysis of how gender trends in our culture put women at particular risk of psychiatric morbidity and ended with a variety of ideas which included the 'mad-bad' dichotomy, the consequences of the Mental Health Act, the internal politics of mental health care and the future of mental hospitals and community care.

The following speaker, Dr Jim Birley, President of the College, entitled his talk 'What is meant by the Political Abuse of Psychiatry'. His sobering analysis reviewed the various ways in which political systems abuse the integrity of psychiatry. In particular, he referred to how direct interference from the State with the clinical relationship between doctor and patient for political reasons can lead to political rather than therapeutic decisions about patient disposal. His talk included reference to psychiatric practice in Russia, Nazi Germany and even the UK, where some psychiatrists believe that psychiatry is "the agent of a racist society". He ended by echoing Dr Huws' point about scientific endeavour, that being prepared to ask questions and test hypotheses is the counterbalance to political abuse.

Mrs Renée Short, Honorary Fellow of the College and Chairman of the Select Committee Report on Social Services (1985), was our final speaker and started by picking up on a question from the audience on the theme of discrimination against women, by pointing out how difficult it is for women to enter Parliament. She enlightened us about the procedures of the House of Commons and how to lobby our MPs. Since her talk she has written comprehensively on this subject in the Psychiatric Bulletin (Short, 1989). She embarrassed us all by asking how many of us actually knew the name of our local MP; a large majority did not. The main part of her talk concerned the work of the Social Services Select Committee (1985) on care of the mentally ill and handicapped in the community. One of the Committees' main conclusions was that community care was not a cheap option. Her talk and the question time which followed inevitably spilled over to some lively discussion about the Government's White Paper Working for Patients.

\section{Reference}

SHORT, R. (1989) Keep up the pressure! Psychiatric Bulletin. $13,406$.

\section{Reading suggestions}

An annual supplement to the College book list, compiled by the Library, is now available. It includes a selection of over one hundred works, all of which have been reviewed favourably in a British psychiatric publication during the past year. List of Books Suitable for a Psychiatric Library, 1988. Price $f 1$. 